particular Ranunculaceae, Fpacridaceae and Rutaceae. He has published several papers, in particular on Ulmus, and is very interested in the application of biometrical methods to taxonomy and the evolution of the angiosperm flower. He will be working in the Botany Division of the Now Zealand Depart. ment of Scientific and Industrial Research.

\section{Zoological Society of London :}

Senior Research Fellowships

DR. I. W. Rowlands has been appointed by the Zoological Society of London as Senior Research Fellow in reproductive physiology. $\mathrm{He}$ will take up his appointment on January 1, 1962, and will be in charge of the Wellcome Institute of Comparative Physiology which is to be built in the Society's grounds next year. For the past twelve years Dr. Rowlands has been on the staff of the Agricultural Research Council and has worked at the Institute of Animal Physiology, Babraham, Cambridge, on problems concerned with the ovarian cycle of mammals. Before this, he worked at the Wellcome Veterinary Research Station, Frant, Sussex. Dr. Rowlands began his research career at the University College of North Wales with Prof. F. W. Rogers Brambell and was afterwards with Dr. A. S. Parkes at the National Institute for Medical Research in London.

Research Fellowships and Studentships

Dr. G. H. MANLEY, who is at present on the staff of the Department of Zoology, University of Nottingham, has been appointed to a research fellowship, and will take up his appointment on January 1, 1962, working initially with Prof. A. St. G. Huggett at St. Mary's Hospital Medical School, on reproductive behaviour of the lower primates. Mrs. A. D. Woodhead, who was been appointed to a research fellowship, has already taken up her appointment, and will work at the Fisheries Laboratory, Ministry of Agriculture, Fisheries and Food, Lowestoft, on the physiology and reproduction of fish. Mr. D. B. A. Symons and Mr. G. Glough have been appointed to research studentships.

\section{Science at the British Council:}

\section{Mr. E. Bolton King}

Mr. E. Bolton KING will retire from the posts of assistant controller, Arts and Science Division (Science Group), and director, Science Department of the British Council, at the end of this year. He will immediately thereafter tako up the post of British Council science officer in Chile. Mr. Bolton King was educated at Warwick School and Balliol College, Oxford, where he was a mathematical exhibitioner and obtained first-class honours in physics finals. He was elected to a research studentship at Christ Church, Oxford, and carried out research at the Clarendon Laboratory, largely on photo-electricity. Later he formed the Oxford Instrument Co. Early in the war he joined the Ministry of Supply Rocket Team under Sir Alwyn Crow and was engaged on rocket development, with special emphasis on proximity fuses, investigation of the performance of British and enemy rocket weapons in the Mediter. ranean theatre, and liaison with rocket development in the United States, where he was an assistant director of the British Commonwealth Scientific Office. At the end of the War he went to Germany in connexion with the British firings of the V.2 rocket and became superintendent of the Ministry of Supply Establishment, Cuxhaven.
Dr. P. A. I. Tahourdin, O.B.E.

DR. P. A. I. Tahourdin will succeed Mr. Bolton King as an assistant controller, Arts and Science Division, with responsibility for various departments, including the Science Department. Dr. Tahourdin graduated in physics at Oxford in 1943 and afterwards obtained a Ph.D. after nuclear work under the late Sir Francis Simon. He joined the British Council in 1946 and has served as science officer in Italy, assistant representative in Yugoslavia, and representative in Israel. He will assume his new duties early in 1962 .

\section{Mr. F. M. Beatty, M.B.E.}

Mr. F. M. BEATty will become director of the Science Department in April 1962. He was trained as a physicist at Cambridge, taking his degree in 1940, and served during the War in the Royal Navy. He joined the British Council in 1946 and has served in the Science Department at headquarters, as science officer in Poland and in Austria, assistant representative/science officer in Brazil and, since 1959, as deputy representative in Pakistan.

\section{Delegation from Academia Sinica in Britain}

ON the invitation of the President and Council of the Royal Society, a delegation from the Academia Sinica in Peking is visiting Britain during October 16November 2. The members of the delegation are: Dr. Chu Ko-chen, vice-president and department member of Academia Sinica (meteorologist); Dr. Pei Shih-chang, department member and director of the Institute of Biophysics, Academia Sinica; Dr. Wang Shou-wu, deputy director of the Institute of Semiconductors, Academia Sinica; Dr. Chang P'ei-lin, deputy director of the Institute of Metals, Academia Sinica. Mrs. Chu is accompanying the delegation. Short visits are being made to Cambridge, Edinburgh and Oxford; and Dr. Chang is also visiting Sheffield. Visits will be made to university scientific departments, the National Physical Laboratory, the National Chemical Laboratory and other seientifie institutes. On October 19 a special presentation and lecture on "Astronomy in Classical China" was arranged at the London Planetarium.

\section{The Wellcome Trust:}

Grants for Research on Tropical Anæmias

THE Wellcome Trustees are to provide up to $£ 100,000$ to assist an integrated programme of research by several groups of workers into the severe anæmias prevalent in tropical countries, with special reference to the malabsorption syndrome and tropical sprue. The Trustees already support work in this field by Dr. Henry Foy and Dr. Athena Kondi at the Medical Research Loboratories, Nairobi, Kenya, and Dr. Selwyn Baker and others at the Wellcome Sprue Research Unit at the Christian Medical College, Vellore, South India. Under the new arrangements the work of both teams will be associated with that of a new Wellcome Laboratory of Tropical Hæmatology which is to be established in Prof. J. V. Dacie's department at the Postgraduate Medical School of London, Hammersmith. The total allocation of $£ 100,000$ for the work on tropical anæmias and kindred disorders is made up as follows: $£ 45,000$ to build and equip the Wellcome Laboratory of Tropical Hæmatology at Hammersmith; $£ 14,000$ to organize and maintain a scheme of close co-operation between 